For Internal Distribution Only

Accelerator Division

Alternating Gradient Synchrotron Department

BROOKHAVEN NATIONAL LABORATORY

Upton, New York 11973

Accelerator Division

Technical Note

AGS/AD/Tech. Note No. 444

Shielding for the AGS J10 Scraper

E.J. Bleser

September 13, 1996 


\title{
SHIELDING FOR THE AGS J10 SCRAPER
}

\author{
Edward J. Bleser
}

\section{SUMMARY}

This note documents the design of the shielding which will be installed at $\mathrm{J}-10$ in the AGS tunnel to shield the new AGS scraper

\section{INTRODUCTION}

Section III develops from the literature formulas for predicting the induced activity around the scraper. Section IV reports the ALARA guidelines for effluents. Section V uses the formula of Section III to demonstrate that the local shielding specified for the scraper meets the ALARA guidelines.

\section{CALCULATION OF THE LONG-LIVED INDUCED ACTIVITY IN THE SOIL AROUND THE AGS J10 SCRAPER}

This section is based on reference 1 which calculated the distribution of all the long lived radio-isotopes produced in the soil surrounding a lead target bombarded by $10^{13}$ protons per second for 25 years. The only two nuclides that approach the ALARA guidelines are tritium, ${ }^{3} \mathrm{H}$, and sodium $22,{ }^{22} \mathrm{Na}$, the others being either short lived, of low yield, or not leachable. Table 1 summarizes the pertinent results from Table III of reference 1.

In order to generalize these results we make certain assumptions.

a.) The activity falls off as a function of radius. We assume cylindrical geometry applies and that the activity falls off as $1 / \mathrm{r}$.

b.) The activity falls off as a function of the distance (often called the mass density thickness) measured in terms of mass per unit area, that is as a function of the integrated amount of side-shield material between the beam center line and the measurement point.

c.) The activity production is independent of the kind of side-shield material but is proportional to the density of the material.

d.) The activity is proportional to the proton energy to the 0.8 power.

e.) This calculation is taken longitudinally only for that one meter length where the activity is at a maximum. Averaging over a greater longitudinal distance would reduce the calculated activity.

In order to determine the function in assumption b.), we multiply the activities in Table 1 by the mean radius of each annular region and scale the first point by the ratio of the 
densities of soil to concrete. The results are given in Table 2 and plotted in Figures 1 and 2 . For ${ }^{22} \mathrm{Na}$ the activity as a function of radius and shielding density is given by:

$$
y(r)=I *\left[(E / 3)^{0.8}\right]^{*}[\rho(r) / 1.8]^{*}[(1.82 E-04) / r] * \exp \{-9.33 E-3 * x(r)\}
$$

where:

$\mathrm{r}=$ radial distance from source to measurement point in centimeters

$y(r)=$ activity of ${ }^{22} \mathrm{Na}$ in Curies per cubic centimeter at radius $\mathrm{r}$

$\mathrm{I}=$ steady state proton intensity incident on the scraper in units of $10^{13}$ protons per second

$\mathrm{E} \quad=$ proton energy in $\mathrm{GeV}$

$\rho(r)=$ density in grams per cubic centimeter at $\mathbf{r}$

$\mathrm{x}(\mathrm{r})=$ integrated material from source to $\mathrm{r}$ in grams per square centimeter

The equation for tritium is very similar but the tritium concentration is not as limiting as the

${ }^{22} \mathrm{Na}$ concentration. Appendix I gives the 1/e fall-off of the ${ }^{22} \mathrm{Na}$ activity for various shielding materials.

\section{ALARA GUIDELINES}

The As Low As Reasonably Achievable (ALARA) guidelines for the concentration of activities in the soil water around the scraper enclosure are given in Table 4.1.2.a of reference 2. They are $1 \mathrm{E}-08$ Curies per cubic centimeter for tritium and, most importantly, $5 \mathrm{E}-11 \mathrm{Ci} / \mathrm{cc}$ for ${ }^{22} \mathrm{Na}$.

\section{SHIELDING DESIGN}

The scraper is designed to have 55 centimeters of iron around the impact point with in general 350 centimeters of drift space to the tunnel wall which is on average 35 centimeters thick. Assume a $24 \mathrm{GeV}$ beam energy. Assume an annual average beam intensity equivalent to that achieved in FY 1995 of $0.5 \mathrm{E} 13$ protons per second and assume that averaged over a year $5 \%$ of this beam winds up in the scraper. Then the equation above can be used to calculate the results shown in Figure 3 which shows that the activity in the first few centimeters of soil outside the tunnel is $3.3 \mathrm{E}-10 \mathrm{Ci} / \mathrm{cc}$. The activity concentration in the effluent water from the soil around the tunnel which will be produced by this level of activity in that soil is calculated in Table 3. Only $7.5 \%$ of the ${ }^{22} \mathrm{Na}$ produced in the soil is leachable. ${ }^{3}$ Ten per cent of the soil is water which gives a concentration factor of ten. However a calculation based on some simple geometrical assumptions gives a dilution factor of 9 . The activity in the soil falls off by $1 / \mathrm{e}$ in 60 centimeters. Assume that water flowing through this area passes on the average through 60 centimeters of activated soil. The fraction of water in the soil is $10 \%$, as above, which gives 6 centimeters of water. The average annual rainfall passing into the soil is 55 centimeters, which gives a dilution of $55 / 6=9$. The overall concentration factor for activity in the effluent water from the leachable activity in the soil 
is 1.1 . This gives finally a concentration of activity in the effluent of $2.7 \mathrm{E}-11$, one half of the ALARA guide of 5E-11.

\section{OPERATING CONDITIONS}

A conservative calculation indicates that normal operations will be well within ALARA guidelines. The actual beam lost in the scraper can be easily monitored with thermo-luminescent detectors, as in the booster, if that seems desirable. Laboratory effluents are closely monitored, and any increases in activity will be quickly observed.

\section{REFERENCES}

1. ORNL-TM-3033, Calculation of the Long-Lived Induced Activity in the Soil Around High-Energy Accelerator Target Areas, T. A. Gabriel, August 12, 1970.

2. AGS FINAL SAFETY ANALYSIS REPORT, D. Beavis, G. Bennett, R. Frankel, E. T. Lessard, M. Plotkin, August 11, 1993.

3. P.J. Gollon, N. Rohrig, M.G. Hauptmann, K. Mclntyre, R. Miltenberger, J. Naidu, "Production of Radioactivity in Local Soil at AGS Fast Neutrino Beam", Informal Report BNL 43558. 
TABLE 1

Activity due to Individual Nuclides Averaged over

The Interval $\mathrm{z}=1$ meter to $\mathrm{z}=2$ meters

And over the Indicated Radial Intervals

Number of $3-\mathrm{GeV}$ Proton $\mathrm{Pb}$ Nucleus Collisions/sec $=10^{-1} 13 / \mathrm{sec}$ Time of irradiation $=25$ years Time after shutdown $=1$ month From Table III of Reference 1

\begin{tabular}{|c|c|c|c|c|c|}
\hline INNER & OUTER & MATERIAL & DENSITY & \multicolumn{2}{|c|}{ ACTIVITY } \\
\hline $\begin{array}{c}\text { RADIUS } \\
\mathrm{cm} .\end{array}$ & $\begin{array}{c}\text { RADIUS } \\
\mathrm{cm} .\end{array}$ & & grams/cc & $\begin{array}{c}3_{\mathrm{H}} \\
\mathrm{Ci} / \mathrm{CC} \\
\end{array}$ & $\begin{array}{r}22 \mathrm{Na} \\
\mathrm{Ci} / \mathrm{CC} \\
\end{array}$ \\
\hline 122 & 152 & CONCRETE & 3 & $1.56 \mathrm{E}-06$ & $1.49 \mathrm{E}-06$ \\
\hline 152 & 183 & SOIL & 1.8 & $2.61 \mathrm{E}-07$ & $3.56 \mathrm{E}-07$ \\
\hline 183 & 244 & SOIL & 1.8 & $8.41 \mathrm{E}-08$ & $1.30 \mathrm{E}-07$ \\
\hline 244 & 335 & SOIL & 1.8 & $1.67 \mathrm{E}-08$ & $2.77 \mathrm{E}-08$ \\
\hline 335 & 457 & SOII & 1.8 & $1.70 \mathrm{E}-09$ & $3.32 \mathrm{E}-09$ \\
\hline
\end{tabular}

TABLE 2

Input for Fitting Procedure

\begin{tabular}{|c|c|c|c|c|c|}
\hline MEAN & \multicolumn{2}{|c|}{ ACTIVITY } & ACTIVITY & RADIUS & INTEGRATED \\
\hline $\begin{array}{c}\text { RADIUS } \\
\mathrm{cm} .\end{array}$ & $\begin{array}{c}{ }^{3} \mathrm{H} \\
\mathrm{Ci} / \mathrm{CC}\end{array}$ & $\begin{array}{l}{ }^{22} \mathrm{Na} \\
\mathrm{Ci} / \mathrm{CC}\end{array}$ & $\begin{array}{c}{ }^{3} \mathrm{H} \\
\mathrm{Ci} / \mathrm{cm}^{2}\end{array}$ & $\begin{array}{c}22 \mathrm{Na} \\
\mathrm{Ci} / \mathrm{cm}^{2}\end{array}$ & $\begin{array}{c}\text { DENSITY } \\
\text { grams } / \mathrm{cm}^{2}\end{array}$ \\
\hline 137 & $9.36 E-07$ & $8.94 E-07$ & $1.28 \mathrm{E}-04$ & $1.22 \mathrm{E}-04$ & 45 \\
\hline 167.5 & $2.61 \mathrm{E}-07$ & $3.56 \mathrm{E}-07$ & $4.37 \mathrm{E}-05$ & $5.96 \mathrm{E}-05$ & 117 \\
\hline 213.5 & $8.41 \mathrm{E}-08$ & $1.30 \mathrm{E}-07$ & $1.80 \mathrm{E}-05$ & $2.78 \mathrm{E}-05$ & 199.8 \\
\hline 289.5 & $1.67 E-08$ & $2.77 \mathrm{E}-08$ & $4.83 \mathrm{E}-06$ & $8.02 \mathrm{E}-06$ & 336.6 \\
\hline 396 & $1.70 \mathrm{E}-09$ & $3.32 \mathrm{E}-09$ & $6.73 \mathrm{E}-07$ & $1.31 \mathrm{E}-06$ & 528.3 \\
\hline
\end{tabular}


TABLE 3

\begin{tabular}{|c|c|c|c|}
\hline 1 & Activity in soil from Graph 3 & $3.3 E-10$ & $\mathrm{Ci} / \mathrm{Cc}$ \\
\hline 2 & $\begin{array}{l}\text { Available activity since } \\
\text { only } 7.5 \% \text { of } 22 \mathrm{Na} \text { is leachable }\end{array}$ & $2 \cdot 5 \mathrm{E}-11$ & $\mathrm{Ci} / \mathrm{CC}$ \\
\hline 3 & Fraction of soil that is water & 0.1 & \\
\hline 4 & $\begin{array}{l}\text { concentration facter } \\
1 \text { unit vol of water exposed to } \\
10 \text { unit volumes of soil }\end{array}$ & 10 & \\
\hline \multirow[t]{6}{*}{5} & Dilution factor & & \\
\hline & $\begin{array}{l}\text { a. Activity is essentially contained in a } \\
1 / e \text { thickness of irradiated soil }\end{array}$ & 60 & $\mathrm{~cm}$ \\
\hline & b. fraction of soil that is water & 0.1 & \\
\hline & c. height of water column in soil & 6 & $\mathrm{~cm}$ \\
\hline & $\begin{array}{l}\text { d. annual rainfall that percolates } \\
\text { down to ground water }\end{array}$ & 55 & $\mathrm{~cm}$ \\
\hline & e. dilution $=55 / 6$ & 9 & \\
\hline 6 & $\begin{array}{l}\text { Overal concentration factor of activity } \\
\text { from soil to water }\end{array}$ & 1.1 & \\
\hline 7 & Activity in effluent & 2. $7 \mathrm{E}-11$ & $\mathrm{Ci} / \mathrm{Cc}$ \\
\hline 8 & ALARA Guide & $5 E-11$ & $\mathrm{Ci} / \mathrm{Cc}$ \\
\hline
\end{tabular}


Fig. 1 ACTIVITY * RADIUS vs SHIELDING for ${ }^{22} \mathrm{Na}$

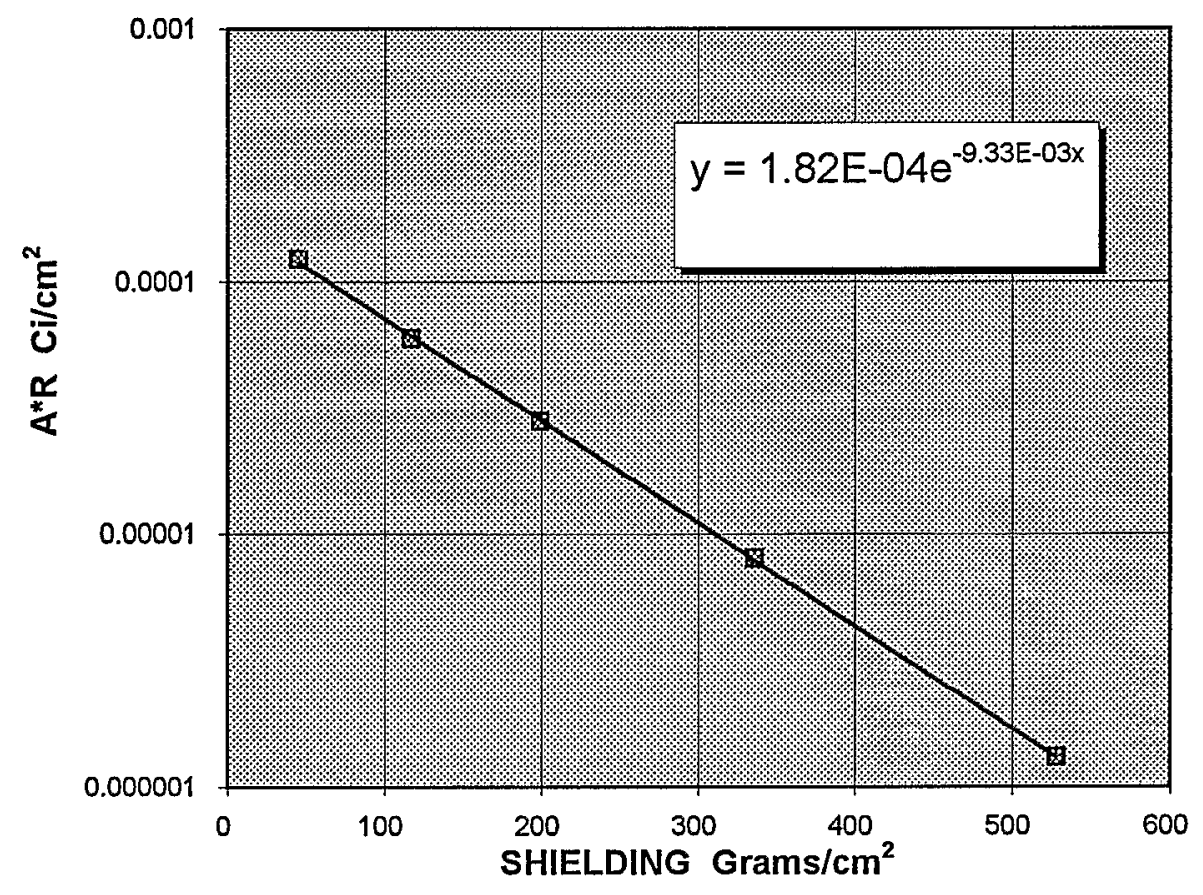

Fig. 2 ACTIVITY * RADIUS vs SHIELDING for ${ }^{3} \mathrm{H}$

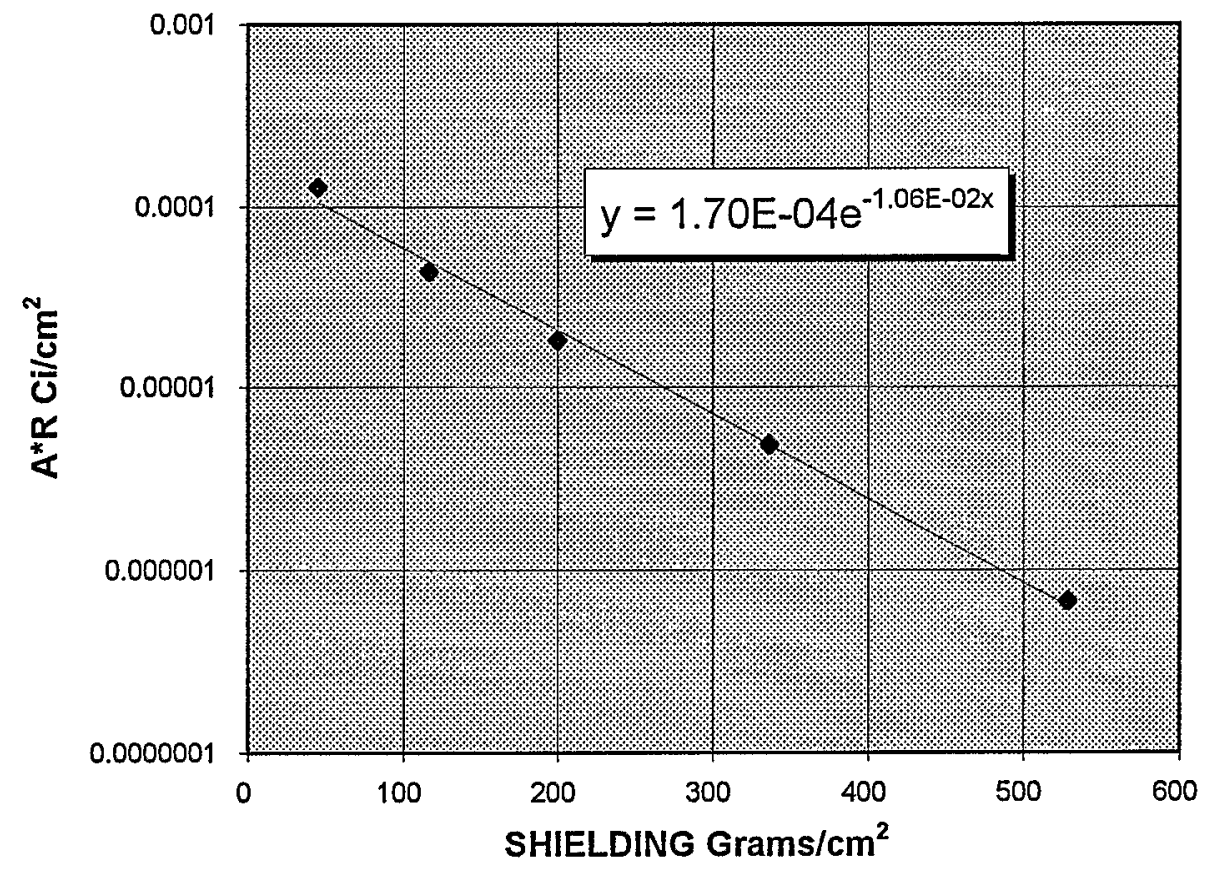


Fig 3 ACTIVITY vs RADIUS

FOR J-10 DUMP WITH 55 CM OF IRON SHIELDING

AT 1995 INTENSITY WITH 5\% LOSS AT FULL ENERGY

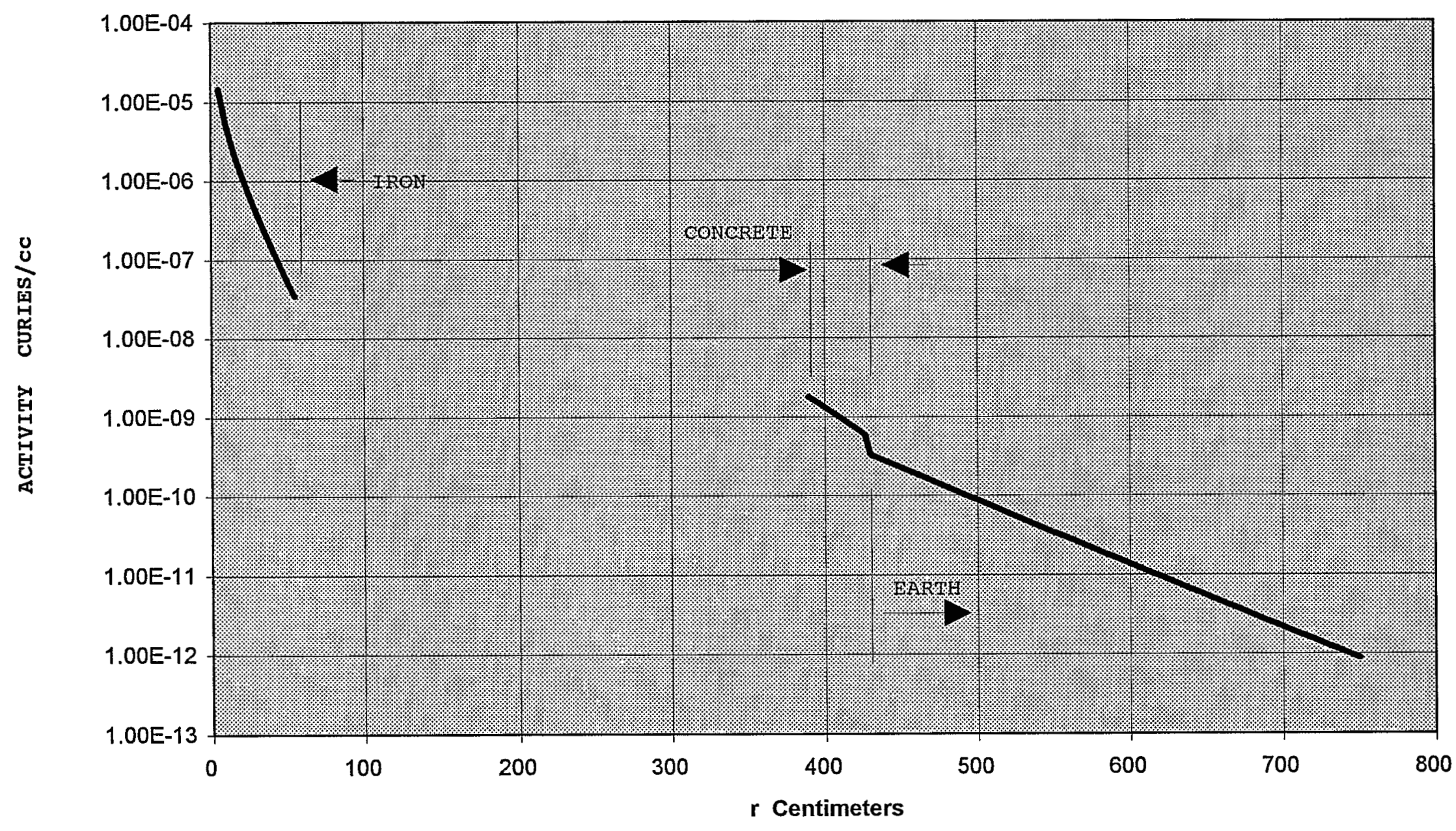


APPENDIX I

ABSORPTION LENGTHS

\begin{tabular}{|c|c|c|c|c|}
\hline MATERIAL & $\mathrm{K}$ (material) & Units & $L=1 / K$ & Units \\
\hline EARTH & 0.0168 & $\mathrm{~cm}^{-1}$ & 60 & $\mathrm{~cm}$ \\
\hline CONCRETE & 0.0280 & $\mathrm{~cm}^{-1}$ & 36 & $\mathrm{~cm}$ \\
\hline IRON & 0.0728 & $\mathrm{~cm}^{-1}$ & 14 & $\mathrm{~cm}$ \\
\hline
\end{tabular}

